\title{
Sustainable Use and Management of Sloping Fields in the Mountainous Area of Vietnam: Present Situation and Solution
}

\author{
Xuan Minh Tran \\ Institute of Land Management \\ Northeastern University \\ Shenyang, China 110819
}

\author{
Guoping Lei \\ Institute of Land Management \\ Northeastern University \\ Shenyang, China110819
}

\begin{abstract}
Vietnam has a total natural area of 33,096,700 hectares. Of which, agricultural land is $26,822,900$ ha, including agricultural land of $10,231,700$ hectares and forest land of 15,845,200 hectares; unused hill and mountainous land of 1,987,400 hectares. According to the recent survey data on sloping fields, the upland areas of ethnic minorities in upland provinces is currently about $\mathbf{1 . 2}$ million hectares and are distributed at altitudes of $300 \mathrm{~m}$ or more, including: 597,920 hectares of rotational sloping fields at altitudes of $300-700 \mathrm{~m}$; 293,680 hectares of upland area at elevations of $700-000 \mathrm{~m}$; 267,710 hectares of upland area at elevations of $1000-1700 \mathrm{~m}$; 40,390 hectares of upland area from $1,700 \mathrm{~m}$ or more. Cultivation method of upland is mainly extensive cultivation, forest burning, cuttings and seedlings. Crop productivity depends entirely on nature and land. Crop structure in slope cultivation remains rarely changed: the area of food crops such hilly rice, cassava, corn and sweet potato accounts for $\mathbf{7 0 - 7 5 \%}$ of cultivated area. Area of other crops such as squash, vegetables, beans, industrial plants, local specialties accounts for $\mathbf{2 5 - 3 0 \%}$. Production is self-demand-self supply for the daily demand, fragmented, small, with little or no ability to produce goods. Solutions are such as planning and stable and long term upland allocation; Promotion of advocacy and strengthening agricultural and forestry extension; In terms of policies and mechanisms; Scientific and technological solutions; Strengthening guidance, inspection and supervision; ... will solve the problems is that besides maintaining the practice of shifting cultivation, but not large forest destruction; Sustainable slope cultivation on the basis of ecological environment protection; Ensuring the friendliness of economic development to improve living standards and protection of forest resources and natural environment.
\end{abstract}

Keywords-slope cultivation; sustainable production; slope degradation

\section{INTRODUCTION}

Vietnam is an agricultural country but the total area of land currently used for agriculture accounts for more than $20 \%$ (only 0.1 hectares of agricultural land per capita). Meanwhile, wild land has over 10 million hectares, accounting for more than $30 \%$ of natural area, or one third of the country area has become deserts. This shows a great waste in the poverty of an underdeveloped agriculture. If only in the midland - mountainous areas, the situation is much more dangerous. Because nearly $90 \%$ of the land is concentrated in hilly areas, almost $40 \%$ of the natural area has become a desert or one hectare of farmland in the area has nearly 5 ha of wild land [1].

Slope cultivation - a form of primitive agricultural production of the tropics - takes an important place in the physical and spiritual life of human beings, is a manifestation of the close bond between the man and nature. Slope cultivation can be considered a form "shifting cultivation" of the ancestors of Vietnamese and other ethnic groups living in the mountainous areas of our country, where the period of cultivation is usually shorter than duration of abandonment. The farming system consists of the following stages: Forest clearing - burning - clearing - cultivation for seedling abandonment [2]. According to data from the Forest Planning Survey Institute, 58.2\% of Vietnam's hilly and mountainous area have a slope of over 200, while slope cultivation is usually conducted on slopes of more than 250 with major crops such as upland rice, maize and cassava, therefore, the slope cultivation has been a popular form of farming for many ethnic groups living in upland areas [3-4].

Although the state has made many efforts to gradually reduce the area of slope cultivation and gradually move to fixed cultivation with intensive cultivation, so far this form of farming has continued to exist in many mountainous places. The cause of this existence is due to:

Food security remains a problem in many upland areas, although we have rice for export [5];

Slope cultivation is a traditional farming method that has a longstanding relationship with sloping landowners both in terms of culture and spiritual life [6];

Labor productivity is 2-3 times higher than labor productivity in the Red River Delta and the Mekong River Delta, if rice is considered as comparable unit [7];

Upland is an important food production area and provides food in places where there are no conditions for developing wet rice. [8] 
Thereby, it can be seen that slope cultivation is still a form of agricultural production that is important and suitable for highland areas lacking land for intensification of paddy rice, suitable for a part of mountainous farmers in different ethnic groups, whose lives are difficult, less likely to invest, intensive farming and more or less depending on the exploitation of available natural resources. In order to ensure food security and improve the lives of mountainous residents, especially those who are involved in slope cultivation, there is a need for aggressive and easy to implement swidden management practices based on the local experience system and new technical advances aim to effectively exploit land resources in mountainous areas effectively and sustainably.

\section{OBJECTIVES AND METHOD OF RESEARCH}

\section{A. Objectives}

Master the situation of sloping fields production in order to identify strategies for limiting slope cultivation, contributing to forest protection and restoration, and proposing solutions to sustainable cultivation and stabilization of life of the residents in the forest and near the forest.

\section{B. Research Methodology}

Refer to the available maps and documents of the mountainous areas in our country so far.

Use the PRA repaid rural survey methodology to survey and evaluate the cultivation practices of the people, the characteristics of the household economy and the implementation of local policies.

Analyze the strengths, weaknesses, opportunities and threats of SWOT (Strengths, Weaknesses, Opportunities, Threats) to collect, analyze and evaluate information.

Use the typical method to select the object and scope of the investigation.

\section{RESEARCH RESULTS}

\section{A. Present Situation of Sloping Fields Distribution in Vietnam}

According to the statistics of the Forest Planning Survey Institute, Ministry of Agriculture and Rural Development, the sloping fields area of the ethnic minority people in the upland provinces are currently about 1.2 million ha, widely distributed in the slope area of 300 meters or more, of which its concentration in the Northwest is $43 \%$ of the total sloping fields area in the whole country, its concentration in the Northeast is $36 \%$.
TABLE I. Distribution OF SLOPING FiELdS AREA By THE REgION AND THE ALTITUDE

\begin{tabular}{|c|c|c|c|c|c|c|c|}
\hline \multirow{3}{*}{ No. } & \multirow{2}{*}{ Region } & \multirow{2}{*}{$\begin{array}{c}\text { Area } \\
\text { (ha) }\end{array}$} & \multirow{2}{*}{$\begin{array}{c}\text { Ratio } \\
(\%)\end{array}$} & \multicolumn{4}{|c|}{ Altitude (m) } \\
\hline & & & & $301-700$ & $701-1000$ & $1001-1700$ & $\begin{array}{ll}0 & >1700\end{array}$ \\
\hline & Total & $1,199,700$ & 100 & 597,920 & 293,680 & 267,710 & 40,390 \\
\hline 1 & Northeast & 430,140 & 36 & 248,100 & 91,220 & 70,600 & 20,220 \\
\hline 2 & Northwest & 54,050 & 43 & 182,920 & 149,760 & 162,940 & 18,430 \\
\hline 3 & $\begin{array}{l}\text { North } \\
\text { Central } \\
\end{array}$ & 72,500 & 6 & 53,640 & 9,730 & 8,740 & 390 \\
\hline 4 & $\begin{array}{l}\text { South } \\
\text { Central }\end{array}$ & 108,020 & 9 & 86,990 & 14,040 & 6,870 & 120 \\
\hline 5 & Highlands & 73,340 & 6 & 24,640 & 28,910 & 18,560 & 1,230 \\
\hline 6 & Southeast & 1,650 & & 1,630 & 20 & & - \\
\hline
\end{tabular}

The total area of 1.2 million hectares of sloping fields listed in "Table I" includes:

- 840,000 hectares of permanent cultivation land, of which: Approximately 360,000 hectares of H'Mong, Dao, commonly known as terraced fields, are cultivated with one or two rice crops, depending on the capacity of natural water supply with the productivity of 1-2 tons/ha/crop, distributed at altitudes above $700 \mathrm{~m}$ and mainly in watershed protection planning areas. Approximately 480,000 hectares distributed with small scale at the altitudes of $300-700 \mathrm{~m}$, with more favourable natural conditions and market.

- 360,000 hectares of rotational sloping fields (plant short-term agricultural crops for a certain period, then the period of abandonment), of which: Approximately 240,000 hectares of difficult agricultural conditions, very low crop yield, the main mode of cultivation is burning of vegetation in the dry season to cultivate short-term agricultural crops. This is a very important watershed area with a height of over $700 \mathrm{~m}$ and a slope of over $25 \%$, which is home to more than 100,000 H'mong and Dao ethnic people and etc. About 120,000 hectares are distributed in rocky areas with thin soil layer thickness.

\section{B. Method of Cultivatioon}

At present, Vietnam has about 50 ethnic groups who make slope cultivation. Each form of slope cultivation is done by a certain ethnic group.

Cultivation methods of slope fields are mainly extensive, forest burning and destruction and seedling. Crop productivity depends entirely on nature and land. Traditionally, different ethnic groups have different ways of cultivating but are generally expressed in three basic forms: [10-11]

1) Method of progress of H'Mong people: Cultivation from the height of $700 \mathrm{~m}$ or more. Burning and destruction of forest for slope cultivation for a number of years (3-5 years, depending on the quality of forest land) until the soil 
is completely degraded, then move to other areas with good forest and land.

This type of slope cultivation is associated with nomadic ethnic minority communities. They practice only one sloping fields, do not go back to the old slop field, use the natural fertility of the soil after clearing the field for cultivation. Over time, the soil is degraded, is unable to cultivate, and the village moves to the new forest and continues to cultivate. Due to the continuous cultivation, when soil fertility decreases sharply, grass dominates in sloping fields, forest plants are difficult to restore to their original state and if they are restored, it takes long time.

Crop structure is sloping fields rice, maize, cassava and some local special plants, vegetables located near the streams, in the narrow valleys.

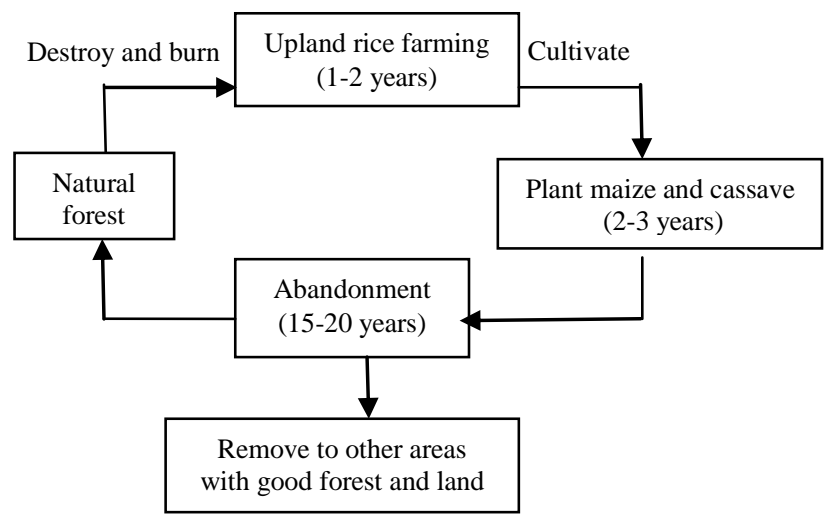

Fig. 1. Method of progress slope cultivation.

This method shown in "Fig. 1" is very destructive, making the forest unable to recover. After the fields, there are only the grass, It causes flash floods, floods in case of heavy rain, eroded soil, worn out and washed away. The status of vacant land, bare hills and mountains has increased rapidly.

2) Method of rotational cultivation: It is carried out by the majority of ethnic minorities represented by Dao, Bana, Ede and Gia Rai ethnic groups and etc cultivating from the height of 300-700m, Sloping fields are cultivated for 2-3 years, then fallow completely for 5-7 years to recover and burn back to slope cultivation.

This method of cultivation is ecologically sound that it is perfectly reasonable if the abandonment duration is maintained and the sloping fields are cleared after a period of regeneration. And if the sloping fields area is not large, they are just like "holes" in the forest and will heal the wounds quickly, and the regeneration will continue. The surrounding forest will be a source of subsistence for the site and will protect it against strong winds and erosion. Forest regeneration on cultivated sloping fields has allowed soil fertility to be restored and people can return to use for subsequent cycles, therefore, the ecosystems are protected and consolidated.
This is a very good slope cultivation method as shown in "Fig. 2". If it is managed and planned, long-term land use will be maintained.

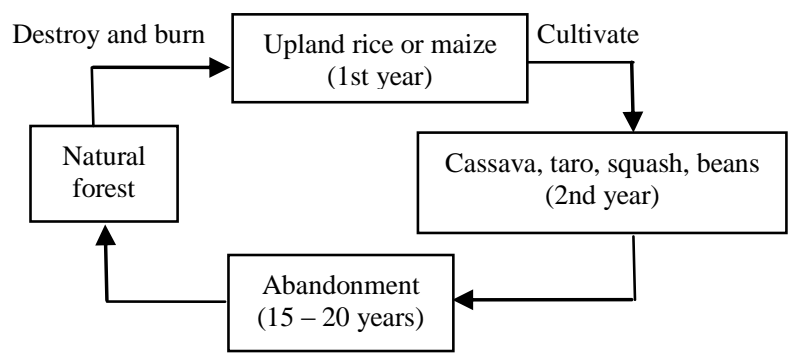

Fig. 2. Method of rotational cultivation.

Crop structure: First year for upland rice, second year for growing cassava; or the first year for maize, the second year for cassava, taro, squash, beans and other local vegetables. From the third year for abandonment for forest regeneration.

3) Supporting slope cultivation: Method of cultivation is mainly done by Muong, Thai, Nung and Tay ethnic groups.

This type of slope cultivation is carried out by the ethnic minority community in which the land is used. They cultivate paddy rice in the valleys around the hills and combine it for slope cultivation in the hills surrounding the rice field. In most cases, they aim to harvest crops for the first year or the second year in the primary crop. Then it is possible to cultivate fallow land or use it in the form of leverage. They often lack the knowledge to develop a long term farming system. The practice of slope cultivation around the hills, near the fields is likely to cause erosion, affecting the fields below the valley.

\section{SWOT Analysis (Strengths, Weaknesses, Opportunities, Threats) for Slope Cultivation in Vietnam}

\section{1) Strengths $(S)$}

a) Potential for expanding farmland: Sloping land is an important part of agricultural production, accounting for about 973 million hectares (about 60\%) of 1500 million hectares of agricultural land in the world. In Vietnam, sloping land accounts for about $74 \%$ of the natural land. In the area of 9.4 million hectares of agricultural land, only 4.06 million hectares are rice land, while over 5 million hectares are mainly sloping land, of which 640,000 hectares are for upland rice cultivation and the remainder are forest land and unused land. Since most of the flat land has been used quite thoroughly, the mountainous area is the only one that has the potential to expand farmland. [12]

Sloping land is distributed in all nine ecological regions of Vietnam, but mainly in the Northern mountainous region, the West Central Coast and the Central Highlands. Most of the sloping land below 15o (accounting for 21.9\%) has been used for agriculture or agroforestry. Area of land with slope ranges from $15 \mathrm{o}$ to $25 \mathrm{o}$ accounts for about $16.4 \%$, the remaining land is sloping over 250 (accounting for $61.7 \%$ ).

The population density of sloping land is much lower than that of the delta, therefore, the production land allocated to the farmers under the new Land Law is much larger than 
the average area of agricultural land in the Red River Delta, only less than 10,000 m2/person in mountainous areas, 3000 - $4000 \mathrm{~m} 2 /$ person. In addition, they are allocated a significant area of agricultural land for the management, protection or production of new forests [13].

Area of unused land is likely to expand the area planted with commodity trees, forest trees is still quite large. This is also a distinguishing feature that needs to pay attention in land use planning and agricultural development investment in sloping land compared to the delta and is also a favorable for provinces with unused sloping land which is possible for economic growth if this investment is exploited advantageously

b) Potential for producing commodity trees and product diversity: Compared with the delta region, crop structure in the mountain areas is much more diversified. While most of the delta plain land is for food production, the mountainous areas have potential land for growing fruit trees and high value food crops excluding temperate vegetables grown in high mountains.

The ability for agricultural production of commodities as raw materials for domestic industry as well as for export is great. These are the areas producing forest trees, industrial plants, fruit trees, shallow flowers of large size, high yield and economic value/commodity, contributing to national economic growth such as: trees for creating raw materials for making paper, processed timber, coffee, pepper, cashew, tea, rubber, cinnamon, latex, pineapple, banana, etc.

Most of the crops grown on sloping land are adapted to natural ecological conditions: the seasonal growth rule of the year, the rain water regime (growth and development in the rainy season), crops are distributed by elevation, slope, capacity to provide natural water and thick soil layer. Therefore, in each sloping land with different ecological conditions, it is possible to set up specific commodity production areas of high economic value while facilitating the concentration of investment in production as well as the market of products: coffee, pepper, cashew, tea, rubber, fruit trees, maize - cassava, sugarcane and etc.

\section{2) Weaknesses (W)}

a) Erosion and washing away: Erosion and washing away are frequent threats to sloping and humid tropics, causing loss of nutrition and fertility, leading to acidification in the soil. These effects are even worse if the arable land does not have cover vegetation or burned land before the rainy season. In West Africa, forest lands converted to nonvegetated cover and severely affected by climate have lost about 115 tonnes of soil per hectare/year. [14]

In the rainy season in the sloping land, there has been deforestation, for long-time cultivation, there area floods and flash floods, flooding which are very dangerous. Only in a short time, sweep floods have devastated fields, sloping fields, villages, causing landslides, floods in the valley.

b) Land degradation: As forest land is destroyed and burned to grow annual crops for food, sloping land in many areas is becoming increasingly degraded. The land use time increases and the fallow time is shortened, therefore, it is not enough to restore soil fertility, resulting in degraded soil and the efficiency of slope cultivation. There are many reasons for limitation and slope productivity instability on sloping land, but the most important reason is due to rapid land degradation both physically and chemically. Increasing aluminium toxicity in the soil is due to acidification of the soil. In addition, there is a significant reduction in trace elements such as P, K, Ca, Mn, Zn. [15]

c) Drought in dry season: Water retention on sloping land is a really difficult problem, therefore, the cultivation depends heavily on rainfall. There are always severe droughts in the dry season. In many areas, there is not enough water for humans or animals. Drought is the main difficulty for sloping land; if the rain comes only about a month later than expected, a failed crop is certain. Drought in the dry season is due to deforestation as well as indiscriminate cultivation that cannot be controlled on sloping land. [16]

d) Isolation: Many mountainous regions are isolated from development centers, therefore, the infrastructure is very poor. Because of this, it has had an adverse impact on economic development. Due to the backwardness of transportation, many sloping areas are separated from the market, therefore, the demand for goods exchange of people is limited. This has slowed the structural change of the crops (from slope cultivation to slash-and-burn agriculture for annual crops to perennial crops with high economic value) to protect sloping land from erosion.

e) Poverty rate and low cultural level: Population in the sloping land are primarily ethnic minorities with higher poverty rates and lower levels of knowledge than the national average. Erosion protection, water conservation and tree planting for economic efficiency require higher investment and higher farming practices. This is a major shortcoming between sloping land exploitation and qualification and capacity of local residents.

\section{3) Opportunities $(O)$}

a) Government's attention: Our state has a lot of policy advocates with great efforts to prioritize the development of rural mountainous areas, poverty reduction for ethnic minority communities in difficulty in remote and isolated areas. Develop and integrate with general development, especially in agricultural production (exemption and reduction of taxes on agricultural inputs). Encourage the import of animal breeds and crops for high economic efficiency and encourage agricultural exports.

b) Science and technology: Technical science and technology in agriculture have many new achievements that can be applied, especially in the field of production of forest trees of economic value. Not only biotechnology but mechanization shall be also widely applied in agricultural production. The rate of use of machines in works such as soil preparation, irrigation, threshing is increasing; postharvest technology and agricultural product processing industry are also strongly developed. Many agro-processing 
units use modern technology and equipment in production; And also, associate with farmers to implement "lump-sum" production, according to the process from farming to processing and export. Therefore, it has contributed to promoting industrialization and modernization of the agricultural sector, enhancing the added value of products, creating more jobs and improving the living conditions of rural workers.

c) Market: The agricultural market is growing, demand for agricultural products is increasing and diversified. To meet the demand for domestic production and consumption and seek export markets to countries in the region and the world. Develop a strategy to develop high quality agricultural products in the direction of efficiency and sustainability. Limit the maximum use of chemicals in the production, preservation and processing of agricultural products. Agricultural commodity production is driven by the market demand, which serves as the basis for the development of a regional planning strategy and the production of commodity agricultural products. Trade promotion is needed to expand both export and domestic markets. Need to capture accurate information on market demand and competitiveness of commodities as a basis for producing commodity agricultural products.

d) International context: Food security is a matter of global concern. Information on research programs is more abundant, rich in content and diverse in appearance

\section{4) Threats $(T)$}

a) Natural conditions: Unused land area is still very large, accounting for $>40 \%$ of unused land area nationwide. The vast majority of land is bare hills and mountains, which is a serious challenge when planning for land use for agriculture and forestry.

The terrain is high and difficult, the slope is divided, therefore, the land field is fragmented, difficult to irrigate and care, creating other sub-climatic areas between seasons of the year. Winter/dry season; Cold, dry climate causes frost, severe drought for crops because the soil moisture is very low, only less than $30 \%$, sometimes less than $15 \%$. In the bare land, the bare hills, it is only $8-9 \%$ moisture, lower than the moisture for wilts. Therefore, the bare land and sloping land is degraded rapidly due to the erosion and runoff, the washing away of soil with water and nutrients. There are many rainy years, the intensity of heavy rain causes sweeping floods causing landslides on high areas, flooding in the valleys.

Due to the global climate change situation in general and in Vietnam in particular, in the last few decades, it tends to be more and more serious, causing great losses to the lives and conditions of agricultural production in many countries and even hills in our country. Flood, erosion, landslides on steep slopes occur continuously during the rainy season, and prolonged droughts in each dry season result in the loss of large quantities of high-value and unsafe agricultural products. mountainous food. b) Cultivation practices and agricultural production qualification: Nationwide, there are 54 ethnic groups, including 53 ethnic minorities most concentrated in the hills with their own custom and traditions of cultivation, but in general is simple, backward from the life (slope cultivation, slash-and-burn agriculture, vegetarianism, landlessness, soil degradation, water conservation). The educational level of the community is low, lack of information due to poor life, difficult transportation, distance from each other, distance from the city, lack of schools and books. The number of illiterate people is high, over $70 \%$, therefore, the ability to absorb and apply scientific and technological progress and innovation for sloping land cultivation is difficult (the model of backward cultivation). [17]

Free migration from the lowland to mountainous sloping lands to clear the woods and clear the land for agricultural production is not going according to plan and the plan of the State is still increasing in many places. This phenomenon leads to continuous natural disasters (floods, erosion, washing away on high places, floods in low places), sloppy land used in the overload scale is quickly degraded.

Sluggish production of sloping land not only leads to rapid degradation of farmland but also causes poverty. According to statistical surveys of several past years, the percentage of poor households, the number of poorer communes in sloping areas is much higher than in the delta areas and recovery (hunger elimination and poverty reduction) is also very slow. challenge. This is also a great obstacle and challenge for socio-economic development as well as the improvement of land use efficiency in mountainous areas. The poverty will lead to deforestation, backward cultivation (slope cultivation), very low crop yields and degraded soil.

c) Management and support policies: Economic development and poverty reduction programs and projects are to limit the unspent, inefficient and sustainable deforestation of the fields.

The agricultural and forestry extension has not been paid due attention. Some models of cultivation transferred to the people are not suitatble for the financial capacity, traditions, perceptions and qualifications of the people. Some projects transfer technology of planting commodity agricultural products to the people, but do not set up a market or distribution network, making people not sell products.

There are no clear policies and regulations on the management of sloping fields in a systematic and comprehensive way. State management of sloping fields is lack of consistency, many focal points, lack of coordination and general guidance of local governmental authorities.

There is no uniform policy, specifically to ensure sustainable livelihoods on sloping fields such as material, financial, technical, technology and market support policies.

The planning of slope cultivation areas is still limited, not properly attached to land use planning and land and forest allocation. It is of a formality, leading to the status of farming activities which is not planned. From the urgent lack 
of land for cultivation, people have to clear the forest for production.

Local authorities at all levels have not yet organized the management of slash-and-burn cultivation in an effective and regular way, and there is no specific regulation on slash-andburn cultivation. Inspection and supervision are also considered light and sanctions are not strict.

Although the state is very interested in the socioeconomic development of mountainous people, however, investment in infrastructure construction, transportation systems, irrigation works, agro-forestry products processing in the remote areas are too small to meet the requirements.

\section{Proposal of Some Solutions for Sustainable Slope Cultivation}

Based on the results of the assessment of the existing features of traditional slope cultivation and the successes of sloping land cultivation models, we propose some solutions to be implemented.

1) Planning and allocation of land for stable and longterm cultivation: This is the most important element that determines the long-term sustainable management of upland rice cultivation, in order to limit the spread of sloping fields.

First of all, review, categorize and specify the area of cultivated land, classify each type of upland rice suitable for agricultural production, protection forest, production forest, industrial crops, fruit trees, grass-planting and sloping fields continue to be cultivated by farmers in accordance with traditional practices as a basis for the planning of slope cultivation and their support plans, balance the demand to support people making sustainable agriculture and forestry cultivation on sloping fields.

Based on the planning of the sloping fields, and the current state of land use for long-term slope cultivation of each household, consideration should be made in line with the land use planning, land allocation and issuance of land use certificates to the people for long-term agro-forestry production.

2) Promotion of advocacy and promotion of agricultural and forestry extension: Propagandize education for people to be fully aware of the great value of forests, the preservation and protection of natural resources: land, water, forest, raising awareness and knowledge for natural resource management and the impact of slash-and-burn cultivation, disasters caused by deforestation and lack of scientific cultivation on sloping lands such as flash floods, floods, landslides and depletion of water sources; propagate and educate the law on forest protection, environmental protection and natural resources, and knowledge of the State's undertakings in assisting the people in sustainable agro-forestry production on their sloping fields for voluntary participation of the public.

Propagate to the people gradually change the practice of slope cultivation, burned extensive grain to intensive farming to increase productivity in the fields, develop the forest, improve the efficiency of land use to ensure cultivation activities on a planned area.

Develop demonstration models of sloping land cultivation in localities, organize visits to fixed cultivation models that have high yield, productivity and economic efficiency in different geographical areas and for other ethnic groups; Construct lectures to guide people to learn, organize technical training courses for local people.

Select groups of plants and animals on the basis of democratic discussion of the people. The State recommends good, high quality seed varieties that are favored by the market and have a rational structure with land in each region in order to achieve high economic efficiency and ensure sustainable development.

3) In terms of policy mechanism: Support for conversion of intensive cultivation into permanent cultivation, develop agroforestry models and gardens. Support the land reclamation by cultivating the productivity of the trees and animals. Combine investment in the construction of rural and mountainous infrastructure with the funding sources of project 134 and 135 and other capital sources of the Government; build irrigation works to ensure the irrigation conditions for a stable area of paddy rice and stable crops, thus creating a basis for increasing crop production and intensifying crop yields.

Develop procedures and technical measures for planting of each species on the basis of identifying groups of plants and each main tree species suitable to the eco-economic zone; Study natural characteristics and market, pay special attention to the demand and ability of processing, preserve and consume products according to ecological zones.

Set up a system of service centers for supplying seeds, fertilizers, insecticides, agro-forestry-processing establishments, and create markets for the sales of farmer's products based on preferential policies on taxation, finance to call on businesses, projects of international credit institutions with preferential loans.

Set up mechanisms, sources and create conditions for people in mountainous areas to borrow preferential capital of the State through programs and projects and etc.

4) Scientific and technological solutions: Study the orientation of land use planning, layout the structure of plants on different types of topography and altitude with high economic efficiency on the basis of forest protection, environmental protection of land resources and water resources.

Research, test and put into practice the transformation of the structure of plants and animals for production of goods with a view to preserving and developing land resources, exploiting the strengths in forests, land and special plant varieties and indigenous experience, promote the development of low-value, high-value commodities, requiring no large investment and modern means of transport.

Study on the application of agroforestry cultivation models, sloping land cultivation techniques (SALT) suitable 
to each region; develop and apply technologies for the production of agro-forestry products such as mushroom cultivation and processing, medicinal plants, spices and other non-timber forest products; techniques of raising livestock, poultry and veterinary services; Organize and monitor resource management activities.

Implement the project to support upland people in sustainable agro-forestry cultivation on the sloping fields.

5) Strengthening the guidance, inspection and supervision: First of all, unify the coordinating agency: the Forest Ranger Department in coordination with the local authorities at the commune level, the district level departments to supervise.

The monitoring content is the whole set of activities for slope cultivation in the area of the province. Include all households after they have been granted land use right certificates and slash and burn activities outside the planned area.

Be aware of the situation of households violating the regulations on management of swidden cultivation, the productivity of plant and animal species, and the situation of agro-forestry development. Propose management and remedial measures for the allocation of forests for cultivation in each local area and ethnic groups on the basis of the State's legal documents on management of land use, natural resources and environment.

The basic characteristics of slope cultivation and the main solutions for slope cultivation and sloping land production to ensure long-term sustainability are mentioned above, thus contributing to the protection of forest and land resources and the sioeconomic development, the ethnic minority communities carry out the hunger elimination and poverty reduction activities of the Party and the State.

\section{CONCLUSION}

Traditional slope cultivation is a long-standing cultivation practice of cultural identity of ethnic minorities, contributing to the self-demand and supply of the ethnic minority people's life in the long history. With the application of rotational cultivation, the people have learned how to recover the fertility of the land, creating conditions for continuous and sustainable agricultural production to a certain degree.

However, traditional slope cultivation is only stable under certain conditions, when the area of natural forest is large, there is no population pressure and there is no competition in the use and ownership regime on land and forests. At present, all these factors have been altered, the area of wasteland and natural forest is less and more and the population increases strongly affecting the cultivation of sloping fields, which makes traditional slope cultivation become unsustainable. Annual crop yields decrease, natural calamities, floods due to the impact of deforestation has strongly impacted the lives of mountainous people.

But it cannot be said: it is not allowed for slash and burn cultivation completely for ethnic minorities. It is found, besides, it still maintains slope cultivation practices, but does not generate extensive forest destruction. Sustainable slope cultivation is on the basis of ecological environment protection. Ensure the friendliness of economic development to improve living standards and protection of forest resources and natural environment.

\section{REFERENCES}

[1] Bui Quang Toan, "Some issues of sloping fields in the North Wes and directions of use", Institute of Science and Technology of Vietnam, 1991

[2] Do Dinh Sam "Overview of shifting agriculture analysis in Vietnam", Forest Science Institute of Vietnam, 1996

[3] Do Dinh Sam, Hoang Xuan Ty, Nguyen Tu Xiem, "Slope cultivation in Vietnam", Agricultural Publishing House, Hanoi, 1994.

[4] Le Trong Cuc, "Slope cultivation in Vietnam", Hanoi Agricultural Publishing House, 1995.

[5] Ngo Dinh Que and Do Dinh Sam, "Report on the results of research on the model of rotational slope cultivation (1996-1997)", National Conference on Sloping fields Management, Hanoi, 1998.

[6] Hoang Xuan Ty, "Indigenous knowledge of upland people in agriculture and natural resource management", National Conference on Sloping fields Management, Hanoi, 1998.

[7] Nguyen Thanh Ha, "Some results of research on agroforestry systems on hilly land", Journal of Forestry vol.2, 1995; pp: 34 - 40.

[8] Thai Phien, Nguyen Tu Siem, «Sustainable cultivation on sloping land in Vietnam", Agricultural Publishing House, Hanoi, 1998.

[9] Pham Xuan Hoan, "Land use classification in agroforestry development planning with the participation of the public", Forest Science Information - Forestry University No.1, 1998; pp: 14-17

[10] Tran Duc Vien, "Experience in post-fallow land management in Vietnam”, Agricultural publishing House. Hanoi, 2001.

[11] Tran Van Dung, "Assessment of current status of slope cultivation on the plateau of Buon Me Thuot, suggestion of the appropriate use of sloping fields", University of Natural Sciences, Hanoi, 2000

[12] General Statistics Office, "Statistical Yearbook of Vietnam 2016" Statistical Publishing House, 2016.

[13] Le Quoc Doanh, Ha Dinh Tuan, Andre Chabanne, "Sustainable sloping land cultivation", Agricultural publishing house. Hanoi, 2005.

[14] Bui Huy Hien, "Mountainous land: use situation, erosion, degradation and measures to protect and improve fertility", In Upland Agriculture, Situation and Solutions, Agricultural Publishing House, Hanoi, 2003.

[15] Nguyen Tu Siem, Thai Phien, "Mountainous land in Vietnam Degeneration and recovery", Hanoi Agricultural Publishing House, 1999.

[16] Vo Hung, "Transformation of forest structure and soil properties during the fallow of slope cultivation", Journal of Agriculture and Food Industry vol.5, 1999; pp: 45-50

[17] Tran Duc Vien, "Agriculture on Sloping Land: Challenges and Potential”, Agricultural Publishing House, Hanoi, 1996. 